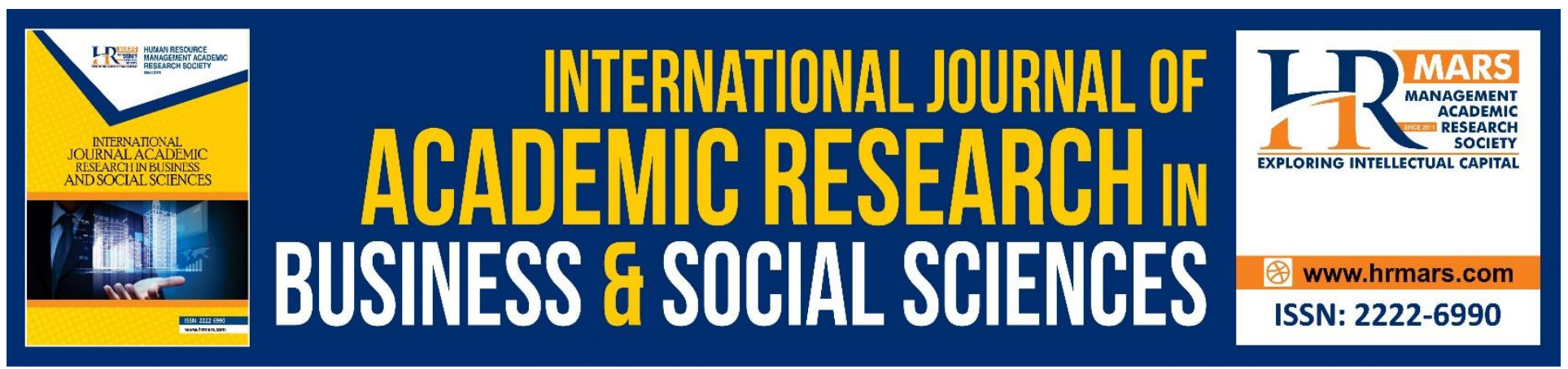

\title{
An Iconographical Analysis Based on the Erwin Panofsky Theory on the Malayness in The Paintings of Amron Omar and Haron Mokhtar
}

Ahmad Hakim Abdullah, Yuhanis Ibrahim and Raja Iskandar Raja Halid

To Link this Article: http://dx.doi.org/10.6007/IJARBSS/v10-i9/7835

DOI:10.6007/IJARBSS/v10-i9/7835

Received: 11 June 2020, Revised: 16 July 2020, Accepted: 18 August 2020

Published Online: 23 September 2020

In-Text Citation: (Abdullah, Ibrahim, and Halid, 2020)

To Cite this Article: Abdullah, A. H., Ibrahim, Y., and Halid, R. I. R. (2020). An Iconographical Analysis Based on the Erwin Panofsky Theory on the Malayness in The Paintings of Amron Omar and Haron Mokhtar. International Journal of Academic Research in Business and Social Sciences. 10(9), 589-601.

Copyright: (C) 2020 The Author(s)

Published by Human Resource Management Academic Research Society (www.hrmars.com)

This article is published under the Creative Commons Attribution (CC BY 4.0) license. Anyone may reproduce, distribute, translate and create derivative works of this article (for both commercial and non-commercial purposes), subject to full attribution to the original publication and authors. The full terms of this license may be seen at: $\underline{\text { http://creativecommons.org/licences/by/4.0/legalcode }}$

Vol. 10, No. 9, 2020, Pg. 589 - 601

http://hrmars.com/index.php/pages/detail/IJARBSS

JOURNAL HOMEPAGE

Full Terms \& Conditions of access and use can be found at http://hrmars.com/index.php/pages/detail/publication-ethics 


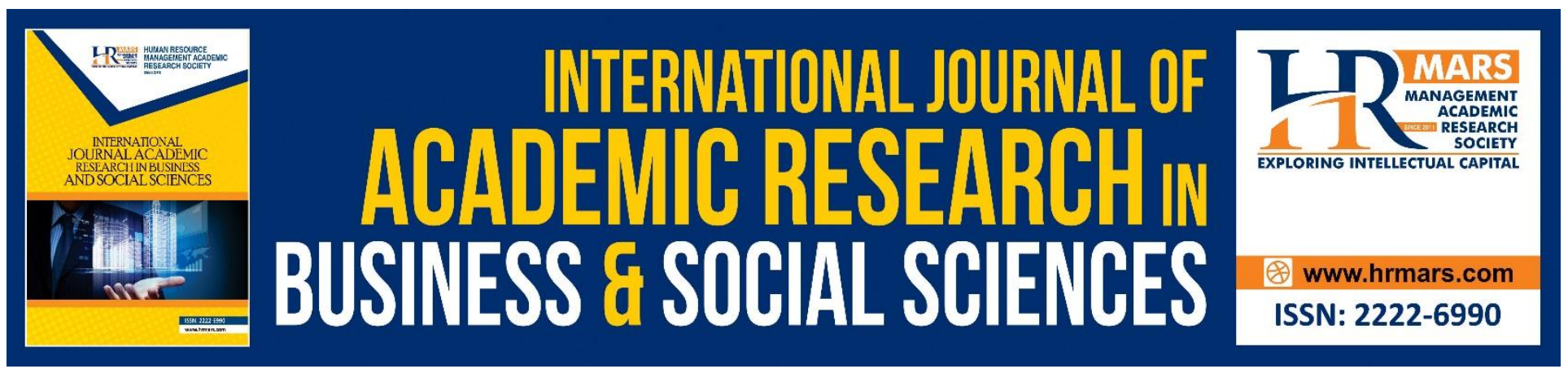

\title{
An Iconographical Analysis Based on the Erwin Panofsky Theory on the Malayness in The Paintings of Amron Omar and Haron Mokhtar
}

\section{Ahmad Hakim Abdullah, Yuhanis Ibrahim and Raja Iskandar Raja Halid}

Faculty of Creative Technology and Heritage,Universiti Malaysia Kelantan, Malaysia Email: hakimabdullah08@gmail.com/c18e026f@siswa.umk.edu.my, yuhanisibrahim@umk.edu.my, rajaiskandar@umk.edu.my

\begin{abstract}
This study aims to analyse the scope of the development of the Malaysian artworks of Amron Omar and Haron Mokhtar paintings through the application of Erwin Panofsky's iconography analysis that involves three levels which are the pre-iconographical description, the iconographical analysis, and the iconological intepretation. This research paper also evaluates the field of fine arts especially the style in the production of two artworks of two painters namely, Amron Omar's "Pahlawan", from the year 1980, and Haron Mokhtar's "Suasana di Kampung", from the year 2007. The theoretical framework of this analysis emphasises on the qualitative methodology by observing the two selected painting artworks by these two Malaysian artists in the scope of the Malay identity observed among local painters. The result suggests that Malaysian painters do instil the value of Malayness identity and symbols in their artworks. The study also clarifies that local painters who are the product of modern Malaysian painters could also create the opportunity for career expansion among eastern artists as well as the entire circle of Malay painters.
\end{abstract}

Keywords: Artworks, Erwin Panofsky, Malayness painting, Haron Mokhtar, Amron Omar.

\section{Introduction}

Theory is a system that aims to explain something based on general ideas that are independent from those being explained. In this regard, a theory will support the strong works among Malaysian artists as well as playing an important role in art paintings, which means the art scene is also organized according to the specialization taken in the institutions created by the government. Many popular western art books, which were famous before the 1970s, displayed the history via a timeline of specific styles of the issue from the painters to the artists but had no direct care towards the sociocultural context where the living environment affects the development of art.

Erwin Panofsky theories use primary data that are divided into a deeper expression of this study in a detailed and in-depth analysis. Apart from that, the institution is also instrumental in the production 
of the works of Amron Omar and Haron Mokhtar. It peels more on the style of work such as expressionism, abstract, abstracts, realism, and is also more surrealistic. In line with this, the involvement of art painters such as Amron Omar and Haron Mokhtar is more than delivering a message in the form of a profound content value in each of the work produced. Generally, the institution has produced painters' works with more emphasis on abstract style, realism, as well as the traditional value of the architectural works for Malaysian artists. Besides that, Malaysian also organises exhibitions in collaboration with parties such as the National Art Gallery, which provides ample rooms for Malaysian artists to express their works and form the intrinsic value in the philosophy of the artworks by Malaysian painters. Not only that, Malaysian artists also has an art faculty that emphasises on teaching and learning.

Problem Statement

Numerous private institutions offer fine art courses that focus on educating and producing talents in the field of art. This creates an intense competition for local artists as the distinctive identity and style of all Malaysian artists in Malaysia is much dosing than the newly-established private institutions in the present period.

Furthermore, the westernised education received by local painters also forms a cultural and style clash in the production of the painting artworks. Malaysian artists also have the tendency for the summary of expressions although there is still an appreciation of the concept of nature as well as the cultural identity of the Malay society. Hence, the key factor in the number of painters in Malaysian will be in the cause of the Malaysian artists to show the advantages and expertise that they can make in each of their artwork.

Besides that, Malaysian artists also receives an appreciation from the National Cultural Congress focusing on regional cultural values. As culture is a part of human life, it possesses an important role in the process of national development in Malaysia where the local personalities should be nurtured as part of the effort to improve the socio-economic and political development. This requires the involvement and contribution from all walks of the society through a continuous process.

\section{Research Objectives}

i. To identify the iconographical content of the Malayness aspects in the paintings of Malaysian artists.

ii. To analyse the Malayness symbol concept in the Malaysian artists' artwork that is being more significant in the Malay symbolism that has been preserved.

\section{Research Questions}

i. What are the iconographical content of the Malayness aspects in the paintings of Malaysian artists?

ii. What is the Malayness symbol concept in the Malaysian artists' artwork that is being more significant in the Malay symbolism that has been preserved?

\section{Significance of Study}

i. As a result of this, the researcher would be able to appreciate the talents of the painters and Malaysian artists from post-independence era to the current era. 
INTERNATIONAL JOURNAL OF ACADEMIC RESEARCH IN BUSINESS AND SOCIAL SCIENCES Vol. 10, No. 9, 2020, E-ISSN: 2222-6990 @ 2020 HRMARS

ii. Besides, the study holds a holistic importance on the relationships between the aspects of Malay culture in the artworks of Malaysian artists and the contribution to the knowledge of Visual Arts.

iii. The study will also highlight the symbol of artworks among Malaysian artists' painters with a detailed description of the content and aesthetics of the artworks.

\section{Literature Review}

Arts is an important part of human life and culture, and it has the capability to attract significant attention and support from the states, commercial companies, and the public at large. Nevertheless, the determinants that posit something as an 'art' and why it should be valued are two theoretical questions in which philosophers have been concerned with for more than 2,000 years. This leads to the emergence of several important answers that introduce and expose newcomers to the field of aesthetics and theory of arts to both the problems and their resolution. In this regard, the philosophy of art is an attempt to answer these questions in a sustained and coherent way while drawing upon the thinking of the major philosophers who have devoted most attention to them. The main intention of such approach is to demonstrate that the philosophy of art (or aesthetics) is directly relevant to the study, appreciation, and practice of the arts (Graham, 2005).

Haron Mokhtar was born on 29th August 1963 in Simpang Lima, Sungai Besar, Selangor. He received his primary education at Sekolah Kebangsaan Simpang (1970-1975), and completed his secondary education at Sekolah Menengah Kebangsaan Sungai Besar, Sabak Bernam. Then, he pursued his bachelor's (BA) in Fine Arts (Painting and Printing) under the Faculty of Arts and Design, Institut Teknologi MARA (ITM), known today as the Universiti Teknologi MARA (UITM). Apart from becoming an artist, Haron Mokhtar also has a keen interest in teaching. In 1998, he managed to get a Diploma in art teaching certificate and started his career as a teacher of Art Education at Sekolah Menengah Kebangsaan Meradong, Sarikei, Sarawak (1989-1990). Today, he teaches art education at Kolej Tingkatan 6 Tunku Abdul Rahman Putra, in Sabak Bernam, Selangor.

Amron Omar is one of the significant painting artists who was born in 1957, in Alor Setar, Kedah. Amron started to paint prior to joining school. His talent in art was discovered when he was at a mere age of three, as he was able to draw some paintings duplicating figures from a storybook about a Malay family's life entitled, "Ahmad Dan Halimah", that was a gift from his brother. It should be said that a Malay leading artist, Hussein Enas, has illustrated all the paintings within the storybook in watercolour. In 1970, Amron Omar focused on painting individuals' activities and was more deeply concentrating on martial art fighters' performances, although he has never learned martial arts himself. The inspiration came from observing his father and brother's martial arts practice. Amron's works are rooted in the inherent nature of Malay tradition and culture. He creates many paintings soon after. His visualization was very sharp and skilled of the offering and its quality was commendable. The artist accurately planned and cautiously delivered shapes, harmony of colours and texture with the greatest sensitivity.

\section{Theory Approach}

This study emphasises on the qualitative methods using the theory because it will be able to elaborate more in-depth in the analysis of data later. It focuses on the external aspects of work by making detailed figures of lines, colours, main subjects, as well as the background of each figure, as presented in the diagram below. In this regard, Erwin Panofsky emphasises more on the aspect of 
INTERNATIONAL JOURNAL OF ACADEMIC RESEARCH IN BUSINESS AND SOCIAL SCIENCES Vol. 10, No. 9, 2020, E-ISSN: 2222-6990 @ 2020 HRMARS

content, meaning of intrinsic, as well as the symbols and themes in visual arts (Panofsky, 1955). The method of the study also explains the subject image, image, and illustration. Erwin Panofsky also emphasises on the development of symbols and semiotic behind their work. In addition, the study also emphasises on the aspect of meaning and formalism in the works of the painters.

\section{Methodology}

The data of the study is obtained by conducting research at the library as well as reading journal articles and scholarly books. The researchers also interviewed the two selected artists in the art painting field by issuing them with 10 questions related to the value of the Malayness symbol in Malaysian paintings. This was followed by an observation of the painters' works at their studios. In addition, the voice recording method was also used to retrieve the needed data from all artists during the interviews.

The study involves several individuals such as Amron Omar and Haron Mokhtar, academicians, and also art artists. It explains how researchers obtain the painters' artwork data from various sources such as the painters' gallery, painting museums, and the painters' studios. However, the analysis of the painters' works was also applied using the observation method of each work associated with the value of the Malayness and cultural symbols. This was followed by an observation on the catalogues and websites which enabled the researcher to be more selective in choosing suitable artworks as the research sample. For sampling purpose, the researcher has selected two paintings which were then analysed based on its formal elements and iconography meaning of the visual elements. The researcher had also interviewed an academician in an art studio.

Figure 1: Mind Mapping of Malay identity Research in Amron Omar and Haron Mokhtar art paintings.

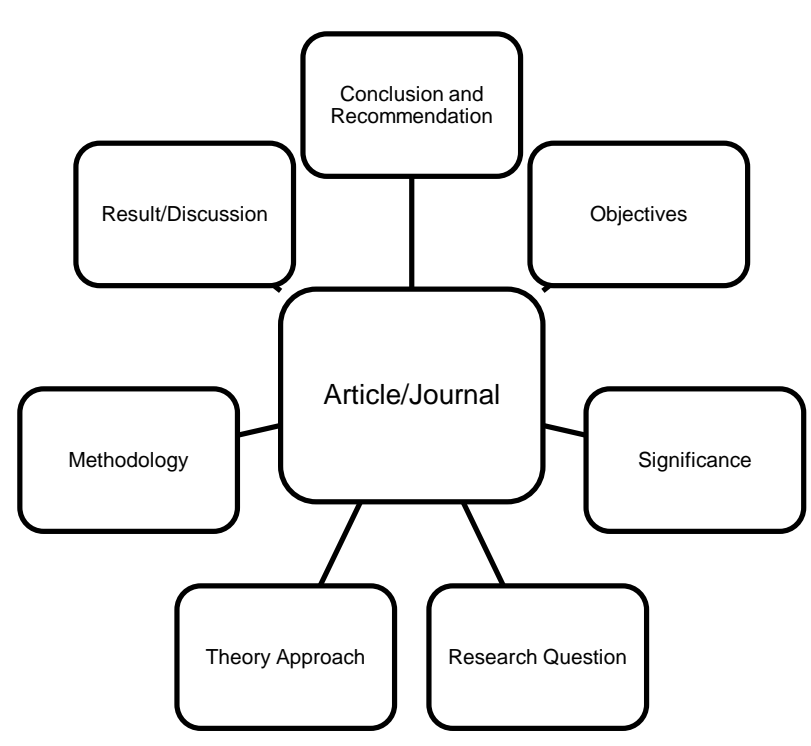


INTERNATIONAL JOURNAL OF ACADEMIC RESEARCH IN BUSINESS AND SOCIAL SCIENCES Vol. 10, No. 9, 2020, E-ISSN: 2222-6990 @ 2020 HRMARS

\section{Result and Discussion}

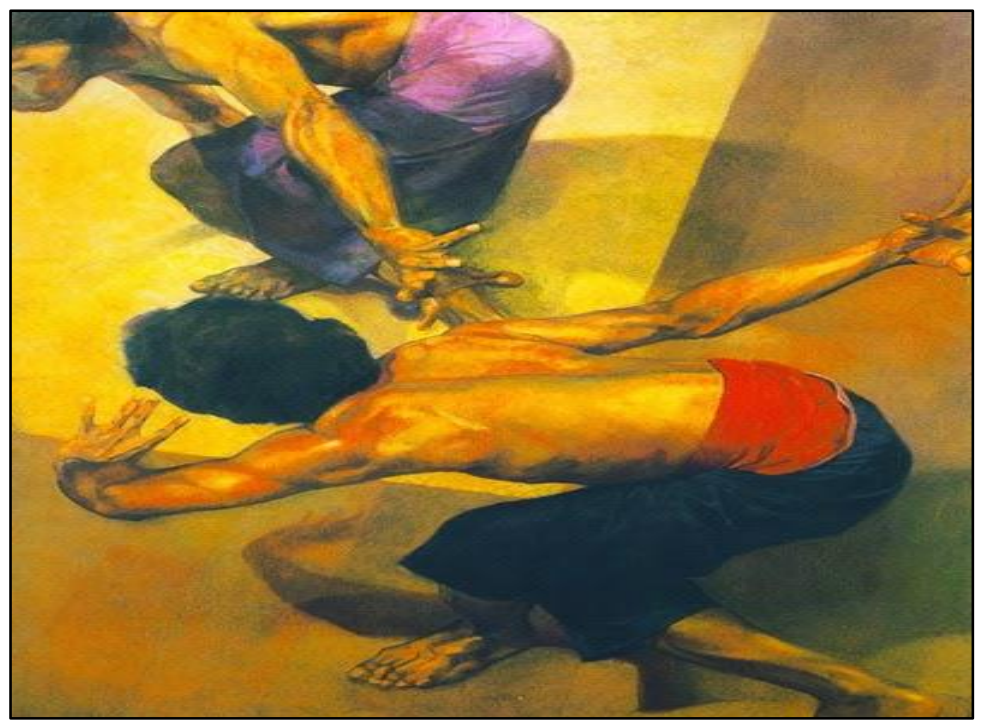

Figure 1 Pahlawan2 (1980)

Amron Omar ,"Pahlawan 2" : (1980), Oil paint on canvas

(Source: https://padlet.com/d080620/abs8wbwt1hfk)

\section{Erwin Panofsky Iconographical Analysis}

\section{The First Level: Pre-Iconographical Description}

This artwork namely, "Pahlawan", was created in the year 1980. The artist, Amron Omar, had used the medium of oil paints on canvas. The size of this work is $182 \mathrm{~cm} \mathrm{X} 164 \mathrm{~cm}$. The above work shows two men who dressed up in traditional Malay garments to show high heroism properties.

\section{The Second Level: Iconographical Analysis}

The painting depicts two shirtless men who are posing with their arms wide extended across their body. Such pose resembles the opening move of the Malay's traditional martial art known as the silat. The body position as well as the facial expression portray the men's physical strength. Amron Omar showcases courage in his work through the muscular effects on the shoulders and arms of the men. These men also show their credibility in portraying the symbol of silat as a spirit of martial art. The media used in this work was oil paint and the technique used was the green technique where transparent male-rays are seemingly made with the production of a variety of colours. The flow used was impressionism as the work can be seen as a masterpiece of watching a fight. The use of colour in this work mostly comprises dark and bright colours such as brown and dark colours, with a shade of brighter lights on the men's body. The work also shows the shape and originality from colours of the muscles on the shoulders and arms. The colours represent a real battle that occurs as exhibited in the figure above.

Amron Omar's work highlights the Malay customs that are concerned with the movements in the Malay martial art. This is shown through the space composition and can be viewed at eye-level. The dominant subjects in this work are the two male objects who wear tied clothing. Their position also suggests that they are engaged in a battle. Through this painting, Amron Omar attempts to convey the value of silat, which is the traditional Malay martial art that is rich in traditions and cultural 
INTERNATIONAL JOURNAL OF ACADEMIC RESEARCH IN BUSINESS AND SOCIAL SCIENCES Vol. 10, No. 9, 2020, E-ISSN: 2222-6990 @ 2020 HRMARS

values. Amron Omar has successfully conveyed the message on the beauty and power of martial arts in the custom and tradition of the Malays.

The work of Amron Omar also describes the cultural attributes of the traditional Malay community in the current life scenario. The success of the works of Amron Omar has been able to give the local character a sincere appreciation even though he presents it using a western frame. A harmonious union between the oriental value and his personality has been adapted into a wise, mature, and impressive nature. Based on the nature and ideas accompanied by the consistency in nature, it is believed that Amron Omar is among the best Malaysian artists.

\section{The Third Level: Iconological Interpretation}

A well-known martial arts specialist would be shaped in the form of a private self-motion training or a true battle art of Silat that can be easily conceptualized as a form of physical martial art that is composed by a number of attacking and defence techniques decorated with the art of softness and beauty in their movement, yet deadly. This creates the elements of a unique culture of the Malay people. In addition, it also describes how Malay warriors are conscious with the self-sustaining spirit among the Malay community.

The Malay Silat art has its own cultural and motion value to protect an individual against enemies. This is because before they initiate a movement they would prepare themselves by opening the body entirely, including hand and foot movements, to show that they are both ready for battle and hold a strong belief to be able to face the enemy after making neat preparations. In addition, Silat also has three categories, which are the art that is used for shows or performance at a theatre, next to reusing the weakness of the opponent to defeat the opponents, and be used in combat.

Not only that, in this artwork entitled, "Pahlawan", it demonstrates the originality of the piece of clothing known as the "kain pelikat", that did not depict a complete outfit. The artist would also like to convey a message that the two men are both prepared to defend themselves. The art of Silat has also been widespread in its influence since the 19th century. Till today, the Malay people who possess silat skills are among the individuals who are members of the community who would be considered as learned or knowledgeable people.

Many of the Malay warriors' outfits up to this day are combined with traditional Malay weapons fittings such as keris, golok, dan lembing. This is due to the fact that in the early days, they did not have other sophisticated and modern weapons equipment to defend themselves. So, the art of Silat will increase the dignity and honour of Malay warriors as the art of Silat possesses a higher value among Malay warriors.

The art of Silat also plays a significant role in the Malay community especially during wedding ceremonies today. The art of Silat indirectly raises the glory of the Malay civilization by demonstrations that are performed during the wedding ceremony. These performances highlight the Silat as a means of self-defence in the event of an attack from the enemy. Not only that, the martial arts also returned nostalgia related with the hulubalang or the old pahlawan who are connected with the traditional Malay world. Apart from the demonstration of the Malay Silat which is being performed during the marriage ceremony, the art of Silat has also proven to have a decent value which is similar to the Malay manners, that is the sense of mannerism that is being practiced in relations to the behaviour and attitudes, that has become a cherished daily practice within the Malay community. 
INTERNATIONAL JOURNAL OF ACADEMIC RESEARCH IN BUSINESS AND SOCIAL SCIENCES Vol. 10, No. 9, 2020, E-ISSN: 2222-6990 @ 2020 HRMARS

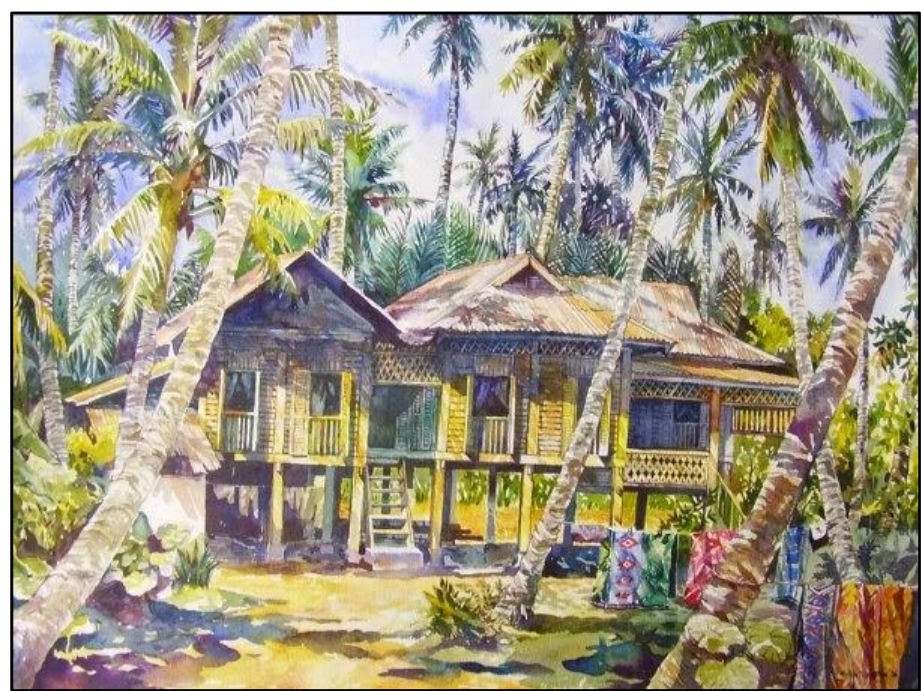

Figure 2: Haron Mokhtar "Suasana di Kampung"(2007) water colour, $640 \mathrm{~cm}$ x 450 $\mathrm{cm}$, Realism

(Source: http://eksplorasiseni87.blogspot.com/2014/03/)

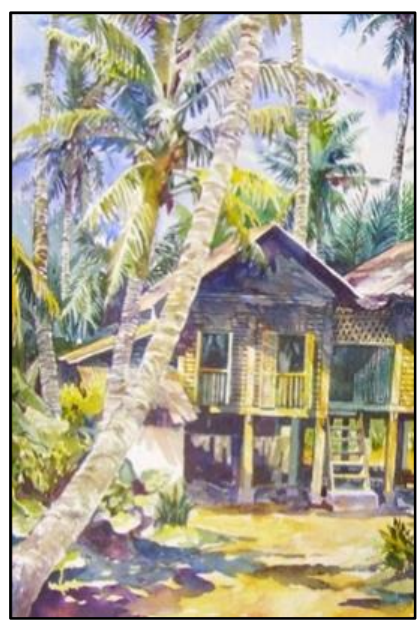

Left side of the work

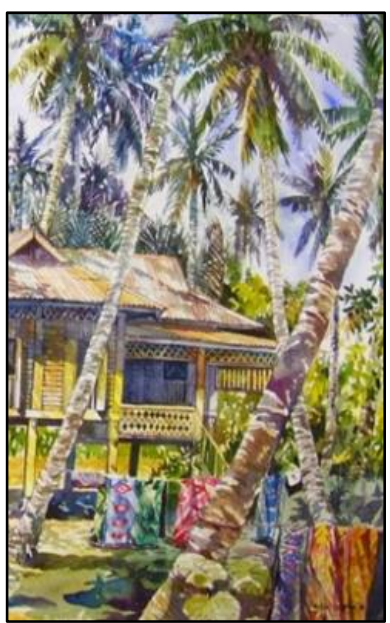

Right side of the work It shows that the work has an assimilation balance

Figure 3: Examples of design principles (Balance)
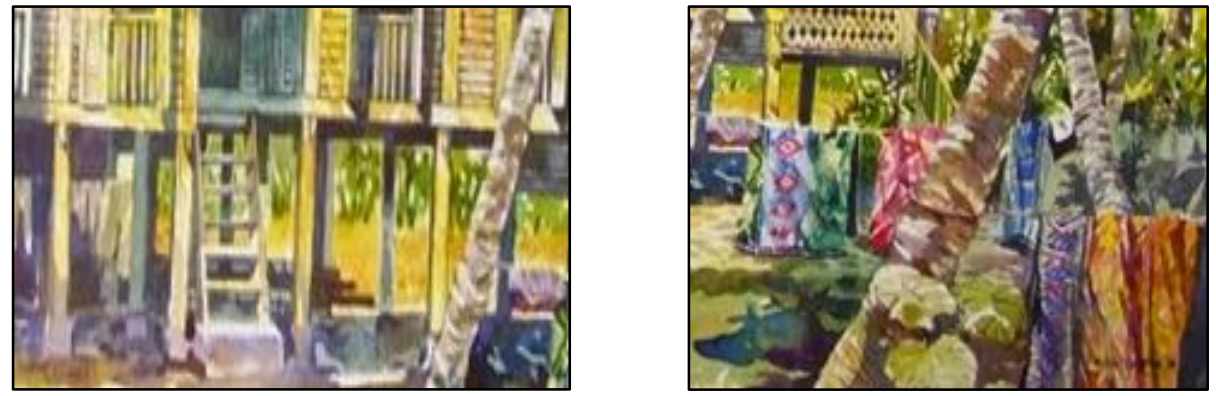
INTERNATIONAL JOURNAL OF ACADEMIC RESEARCH IN BUSINESS AND SOCIAL SCIENCES Vol. 10, No. 9, 2020, E-ISSN: 2222-6990 @ 2020 HRMARS

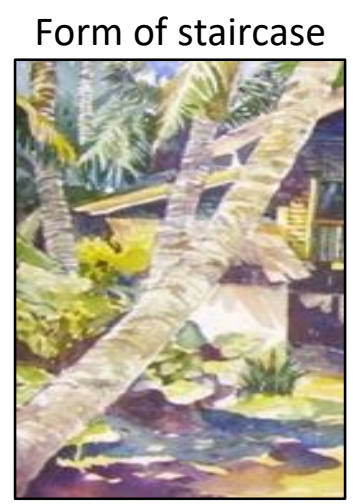

Form of house
The shape of a coconut tree

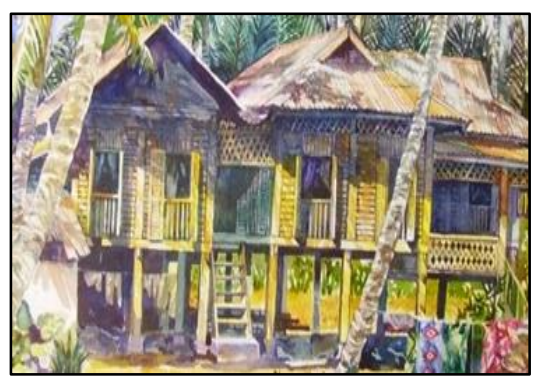

Shape of Batik Fabric

Figure 4 Examples of Elements of Art (Form)

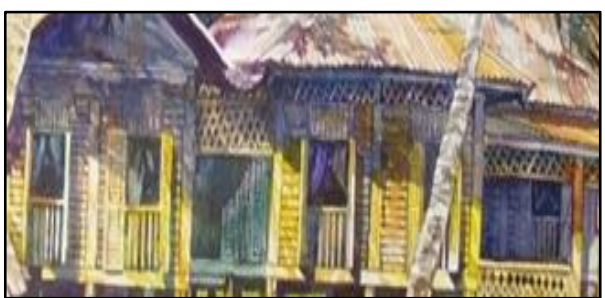

Warm colour (Light yellow on the house window)

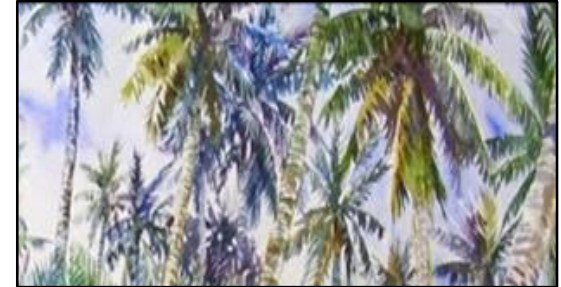

Cold colour (Light blue colour of the sky)

Figure 5: Examples of elements of Art (Colour)

\section{Erwin Panofsky Iconographical Analysis}

The First Level: Iconographical Description

The art of this painter used the medium of watercolour. It is $640 \mathrm{~cm} \mathrm{X} 450 \mathrm{~cm}$ in size. This artist also shows a realism in the whole of his painting. The work of Haron Mokhtar reflects the setting of a peaceful village with a beautiful village house positioned at the centre.

\section{The Second Level: Iconographical Analysis}

The work of the village is sustained by wood materials to state the settlement of the village. It is likely that most people in Malaysia in the older era have a house like this while the majority are now directed towards modernity. Haron Mokhtar attempts to sustain and preserve such tradition in his work for the benefit of future generations. This work is produced using the water paint media and it is presented in the form of realism. The work shows the mood in a clear material used in the work of "Suasana di Kampung". Another aspect to elaborate on the main focus of the work is the village house that dominates the space. In this work, it can be identified that the village house has two staircases where the left staircase is the rear stairs while the staircase on the right is the front stairs. The artistic principle has a union in producing a balanced drawing from the aspect of the artistic element in creating a design principle. The principle of this union can be seen in this painting drawn 
by Haron Mokhtar where he inserts suitable elements and artistic principles to emphasise the colours, size, and balance. Based on the golden colour of the house and the shadow that is reflected towards the front of the house, the time setting in the artwork is interpreted to be around 3 p.m. to 5 p.m.

The work has placed the elements of nature through the coconuts trees that surround the village house. There are also two clothing rails that are tied between the coconut trees. There is a creative and interesting element in this work that is depicted by the clothes and fabrics. At the bottom of the village house there are items that cannot be identified as the area of the logic is dark and there is no indication of its nature.

\section{The Third Level: Iconological Interpretation}

In other contexts, the age of the traditional house is old due to the colour of the wooden panels that appears to be obsolete and dull. There are also elements of typical village houses such as the carvings patterns that usually exist in the states of Kelantan, Negeri Sembilan, Terengganu, and Melaka. A closer observation reveals that there is a small room made from bricks and with a zinc rooftop that is attached with the house, which might possibly be the bathroom located adjacent to the house. In his work, this art painting also describes the value of the Malay culture from the elements of batik sarongs on the clothing rails, reflecting the aesthetics value of the Malay community and life in the village. The batik art of the old era has a more refined value in terms of pattern motifs such as bamboo shoots (pucuk rebung), which gives a sense of reflection to the personality of a person, which is easily formed during childhood, to emphasize that he/she will not be fragile when facing any problems, if educated with adequate knowledge and manners based on Islam.

Apart from that, the main value in Haron Mokhtar's work is observed in the traditional Malay house design that emphasises the art of politically motivated kerawang and awan larat. The awan larat also describes the nature of the Malay girl, which gives the meaning that she is gentle and highlycourteous. The awan larat symbolism is also showcased in the detailing and fineness of the intertwined motifs between the flora and the neatness of the arabesque's own awan larat carving motifs.

This is in line with the teachings of Islam, where the use of other motifs such as a figure and nonflora is strictly prohibited, which includes using an element of fauna which are realistic or excessive. Islam does not allow too much highlight of the element of fauna. This is true because the environment around us is very important, especially with the existence of flora woodcarving in particular carvings at the traditional Malay house which have various distinctive functions. For example, the woodcarving of bunga teratai and daun sayap on a rumah tiang dua belas carvings in Kelantan and Terengganu enhance the ventilation function on the back of every flora motifs wall of the rumah tiang dua belas.

\section{Conclusion}

The findings of this study conclude that cultural and local values are among the most consistent and current themes that are still accepted in the production of artworks among Malaysian painters. The cultural elements of the Malay community can be seen in the works of Amron Omar and Haron Mokhtar. Meanwhile, the elements of martial arts can be seen in the works by Amron Omar. After the National Culture Congress in 1971 (NCC), both of these painters continue to use cultural themes and local values in their work, including elements like bamboo shoots (pucuk rebung) and awan larat 
INTERNATIONAL JOURNAL OF ACADEMIC RESEARCH IN BUSINESS AND SOCIAL SCIENCES Vol. 10, No. 9, 2020, E-ISSN: 2222-6990 @ 2020 HRMARS

in woodcarvings motifs, and batik motifs such as daun sayap and bunga teratai in textiles. The artists' awareness in producing cultural works with local values will continue to be taken into consideration as a sense of commitment and loyalty shown by local artists.

As one of the pioneering institutions, Amron Omar and Haron Mokhtar have to continue showcasing their artistic talents in Malaysia. These Malaysian artists have also become an inspiration in the development of ideas for art institutions as it is among the institutions that create knowledgeable generations in the field of arts and influences the creation of artworks within the artists' circle. Education also has a significant impact on arts education and also serves as a potential solution to the problems of designing the world of western art to the eastern culture.

\section{Theoretical and Contextual Contribution of this Research}

In this research, the Malay values in the production of the various aspects of the study were significantly displayed in terms of the subjects of Haron Mokhtar and Amron Omar's artworks. This visual analysis is clearly displayed in the work of Amron which shows two figures who are practicing martial art in the "Pahlawan" artwork. It demonstrated that the focus of the iconographic analysis is the content of the image, such as the number of figures used, their placing and gestures. Meanwhile, the Erwin Panofsky theory also highlighted the aspect of the third level of iconological interpretation of the symbolic and deeper analysis of each Malayness symbol in the works of Amron Omar and Haron Mokhtar.

Through this third level analysis, a more critical and detailed iconological interpretation are presented in the painting of the Malay traditional house which is closely related with the Malay philosophy in woodcarvings as observed in Haron Mokhtar's artwork of "Suasana di Kampung". The art of Malay Silat in "Pahlawan" artwork of Amron Omar is also related with the Malay identity martial art movements during a certain period in time. The concept of this theory also shows the relationship between images and the Malay cultural values which are being symbolised in the Malay woodcarvings art and martial arts. These three clarifications provide the highest impacts with meaningful values in the representation of the Malay civilization, with the year's style of the National Cultural Congress that analyses the theme and style of paintings by artists in a particular era and at a certain time, with a descriptive analysis using Erwin Panofsky on the artworks of Amron Omar and Haron Mokhtar between the years 1980 to 2007, which have been embodied by these local artists in the art of painting Malay customs.

Through the theory of Erwin Panofsky, the analysis does not only provide an explanation of external or formalistic values but also the other aspects of the Malay culture. This is because iconography signifies the symbols at a deeper level of meaning only to subjective understanding and is often associated with the collective unconscious of a period or nation. The objective of this study is to explain the style of the artists that emphasises a more dramatically-driven value of the Malay cultural contexts in the activities that showcase their civilization. In the meantime, the value of aesthetics in batik is also a symbol of Malay traditions, especially in the artwork presented by Haron Mokhtar. Not only that, Haron Mokhtar also highlights the value of the Malay culture through the philosophy related to the Malay community in the art of the Malay traditional house. Amron Omar highlights the heritage value of the Malay silat through the martial art movements to fight against the enemy. This is because during that era, the art of Silat was designated a high value due to the fact that there were no sophisticated weapons to fight with enemies. Through the rise of the National Cultural Congress 
INTERNATIONAL JOURNAL OF ACADEMIC RESEARCH IN BUSINESS AND SOCIAL SCIENCES Vol. 10, No. 9, 2020, E-ISSN: 2222-6990 @ 2020 HRMARS

in 1971 , it has also uphold professional artwork among Malaysian artists by maintaining Malay identity concepts.

\section{Recommendation}

Following this study, it is suggested that these values and symbols should continue to be preserved in order to avoid it from becoming obsolete and dismissed by current modernity. In this regard, both artists and academicians should work together to preserve the value of the Malay cultural heritage that will sustain its prominence not only among the younger generations but also within the artworks produced in this future. The researchers also encourage Malaysian painters to sustain their support towards the National Congress of Culture (NCC) as part of the effort to preserve and conserve the national heritage in their artworks for the benefits of the future generations.

\section{Acknowledgement}

The author would like to thank the author's main supervisor who is a senior lecturer in the Fine Arts Department, Universiti Malaysia Kelantan (UMK), Dr Yuhanis, and the respected Dr Raja Iskandar Raja Halid, for their guidance and assistance in this study. The author would also like to express appreciation to Mohamad Hadzal Kamarulzalis for his invaluable guidance.

\section{References}

Abdul Malek, S. N. (2019). Biografi, Naratif: Penghasilan Makna Melalui Catan, Kupas Seni. Jurnal Seni dan Pendidikan Seni, 4.

Abdullah, K. H. A., Saini, M. S., Sharip, S., \& Shaharom, M. H. (2016). Seeking help at an Islamic spiritual healing centre: Malaysia's perspective. Journal Mental Health, Religion \& Culture, 19(7), 742751. doi.org/10.1080/13674676.2016.1277986

Ahmad, S. H. (2020). Elemen budaya dalam karya seni catan Malaysia: satu tinjauan. Idealogy, 5(1), 157-164

Ali, Z. (1989). Seni dan Seniman: Esei-esei seni halus. Kuala Lumpur: Dewan Bahasa dan Pustaka.

Amran, K. (2002). Perkahwinan Melayu. Kuala Lumpur: Dewan Bahasa dan Pustaka.

Deraman, A. (2002). Tamadun Melayu dan Pembinaan Bangsa Malaysia. Kuala Lumpur: Dewan Bahasa dan Pustaka.

Benecke, D. W. (1989). Cultural Life in the Federal Republic of Germany. Germany: Bonn Inter Nationes Bonn.

Davies, P. H. J. (2001). Identity, Continuity and Silat: Some Dilemmas For Cultural Continuity In A Time Of Rapid Change [Paper presentation]. Symposium Kebangsaan Masyarakat Malaysia: Isu Dan Cabaran Abad Ke-21, Fakulti Sastera Dan Sains Sosial, University Malaya, Kuala Lumpur.

Denel, B. (1979). A Method for Basic Design and Creativity. Ankara: METU.

Din, H. (2011). Siri Pengajian Islam: Rawatan Penyakit Akibat Sihir) Series of Islamic Medicine Study: Healing Of Ailments Due To Black Magic (Sihir) Malaysia. Islamic Medicine and Welfare \& Darissyifa Cooperative Limited.

Draeger, D. F. (1972). Weapons and Fighting Arts of the Indonesian Archipelago. Tokyo: Charles E. Tuttle Company Incorporation.

Graham, G. (2005). Philosophy of the arts: An introduction to aesthetics. USA and Canada: Routledge. Hasbullah, W. M. D. W. (2018). Konsep Tempur Seni Gayong dan inovasi silat Melayu. Jurnal Pengajian Melayu, 29(1), 262-285. 
INTERNATIONAL JOURNAL OF ACADEMIC RESEARCH IN BUSINESS AND SOCIAL SCIENCES

Vol. 10, No. 9, 2020, E-ISSN: 2222-6990 @ 2020 HRMARS

Hassan, M. K. (1980). Nilai-Nilai Universal Islam Tentang Kesejahteraan Masyarakat. In seminar Nilai dan Norma Masyarakat Malaysia. Kementerian Kebudayaan Belia dan Sukan, Kota Kinabalu, 10-11 Mac, Sabah.

Kari, R., Samin, A., \& Legino, R. (2018). The Sustainability's Motif and Design of Fauna in Malay Block Batik. In International Conference on Social Sciences, Humanities, Economics and Law. European Alliance for Innovation (EAI).

Ku, A. K. M., \& Wong, K. K. (1978). Silat Melayu: The Malay Art of Attack and Defense. Kuala Lumpur: Oxford University Press.

Madoff, S. H. (2009). Art School: Propositions for the 21St Century. New York University: The MIT Press.

Mahamood, M. (2007). Modern Malaysian Art: From the Pioneering Era to the Pluralist Era, 1930s1990s. Utusan Publications.

Musa, N. N., \& Ramli, H. (2014). Identiti Melayu dalam Catan Syed Ahmad Jamal. KUPAS SENI: Jurnal Seni dan Pendidikan Seni, 2.

Nawawi, N. M., Aziz, A., Legino, R., Ahmad, N. H., \& Ismail, N. H. (2015). The Nature of Malay Songket Textile Patterns. Journal Bussiness and Management Quaterly Review, 2/3(6), 41-56.

Noh, H. M., \& Marziana, L. (2013). Manifestasi pandangan dunia Melayu dalam rupa dan jiwa seni catan wanita Melayu tahun 1970-1990. Proceeding penyelidikan pemikiran dan kepimpinan Melayu (IMPAK), Universiti Teknologi MARA. http://ir.uitm.edu.my/id/eprint/12599/

Noh, L. M. M., Haron, H., Samian, A. L., Hasan, A. R., \& Dolah, J. (2015). Analisis formalistik dalam memaknai simbol budaya melayu abstrak. International Journal of Creative Future and Heritage (TENIAT), 3(2), 49-72.

Panofsky, E. (1955). Meaning in the Visual Arts. United States: The University of Chicago Press.

Patria, A. S. (2013). Bauhaus Awal Sekolah Desain, Jurnal Dimensi Seni Rupa dan Desain, 10(1), $27-42$.

Pile, J. (2000). A history of interior Design Third Edition. London: Lauren King Publishing, Ltd.

Rashid, N. A. (2005). Nilai Kesantunan Dalam Konteks Sosiobudaya Masyarakat Melayu. Jurnal Pengajian Melayu, 15(1), 232-253.

Ahmad, S. A. (2003). Sulatus Salatin Sejarah Melayu: Edisi Pelajar. Kuala Lumpur: Dewan Bahasa dan Pustaka.

Sidik, F. (2017). Catan Songket (Faizal Sidik: Songket Paintings). http://faizalsidik.blogspot.com/2017/02/faizal-sidik-catan-songket-faizal-sidik.html

Silah, S., Basaree, R. O., Isa, B., \& Redzuan, R. S. (2013). Tradition and Transformation; the structure of Malay woodcarving motifs in craft education. International Conference on University Learning and Teaching (InCULT), Procedia-Social and Behavioral Sciences, 90, 823-831.

Tillander, M. (2011). Creativity, technology, art, and pedagogical practices. Art Education, 64(1), 4046. doi.org/10.1080/00043125.2011.11519110 